ISSN1027-5495. Functional Materials, 24, No.4 (2017), p. 572-576

\title{
Tribological properties of calcium carbonate powders modified with Tween 40 as lubricant additives
}

\author{
Chen Tianhua \\ College of Machinery and Vehicle, Changchun University, \\ Changchun, Jilin, 130022 China
}

Received August 15, 2017

In this experiment, nanometer calcium carbonate was prepared by metathesis method. The nanometer calcium carbonate was modified by non-ionic surfactant-tween 40 . The nanometer calcium carbonate before and after modification was analyzed and characterized by various methods. Scanning electron microscope (SEM) result show the size of the unmodified nano-calcium carbonate is about 200-400nm, while the particle size of the modified particles is about 200 nanometers. Contact angle indicate that $\mathrm{CaCO}_{3}$ powders become hydrophobic after modified. Moreover the friction and wear properties of Tween $40-\mathrm{CaCO}_{3}$ as lubricant additives in rapeseed oil were evaluated with a four-ball friction and wear tester. Tween $40-\mathrm{CaCO}_{3}$ could improve the anti-wear and friction reducing capacities of rapeseed oil can conclude from the friction results. X-ray photoelectron spectroscope of worn steel surfaces indicated that an absorption film containing rapeseed oil and $40-\mathrm{CaCO}_{3}$ was formed.

Keywords: $\mathrm{CaCO}_{3}$ nanoparticles ; Base oil; additive; tribological property.

Нанометровый карбонат кальция получен методом метатезиса и модифицирован неионогенным сурфактантом 40. Нанометровый карбонат кальция проанализирован и охарактеризован различными способами до и после модификации. Показано, что размер немодифицированного карбоната нанокальция составляет около 200-400 нм, а размер частиц модифицированных частиц составляет около 200 нанометров. Угол контакта указывает, что порошки $\mathrm{CaCO}_{3}$ становятся гидрофобными после модификации. Характеристики трения и износа Tween $40-\mathrm{CaCO}_{3}$ в качестве смазывающих добавок в рапсовом масле оценивали с помощью четырехшарового трения и тестера износа. Tween $40-\mathrm{CaCO}_{3}$ может улучшить способность к изнашиванию и уменьшению трения рапсового масла. Рентгеновский анализ изношенных стальных поверхностей показал, что была образована абсорбционная пленка, содержащая рапсовое масло и $40-\mathrm{CaCO}_{3}$.

Трибологічні властивості порошків карбонату кальцію, модифіковані Tween 40 у якості мастильних добавок. Chen Tianhua

Нанометровий карбонат кальцію отримано методом метатезісу i модифріковано неіоногенним сурфактантом 40. Нанометровий карбонат кальцію проаналізовано i охарактеризовано різними способами до і після модифікації. Показано, що розмір немодифікованого карбонату нанокальція становить близько 200-400 нм, а розмір часток модифікованих частинок становить близько 200 нанометрів. Кут контакту вказуе, що порошки $\mathrm{CaCO}_{3}$ стають гідрофобними після модифрікації. Характеристики тертя і зносу Tween 40- $\mathrm{CaCO}_{3}$ в якості змащувальних добавок в рапсовій олії оцінювали за допомогою четирехшарового тертя і тестера зносу. Tween 40-CaCO 3 може поліпшити здатність до зношування і зменшення тертя рапсового масла. Рентгенівський аналіз зношених сталевих поверхонь показав, що була утворена абсорбційна плівка, яка містить рапсове масло і 40$\mathrm{CaCO}_{3}$. 


\section{Introduction}

Nanomaterials are drawn widely concerned because of their special physical and chemical properties. In the field of tribology, a lot of research on tribological properties of the nanometer particles [1-4] as lubricating oil additives were carried out. It found that nano $\mathrm{CaCO}_{3}$ as a typical lubricating oil additives, can effectively improve the tribological properties of lubricating oil. However, the main reason for limiting the application of nano $\mathrm{CaCO}_{3}$ in lubricating oil is hydrophilic surface characteristics of $\mathrm{CaCO}_{3}$ .Therefore, surface modification of nano- $\mathrm{CaCO}_{3}$ to improve its dispersion performance in base oil will enhance its application potential as lubricant additive. With the increase of the environmental protection consciousness of people in the field of tribology, environment-friendly lube has become a new research hot spot.

Compared to mineral oil, vegetable oil has the advantages of excellent lubrication, biodegradability non-toxicity and so on .Rapeseed oil is selected as the base oil for lubricating oil because of its renewable advantages. In addition, $\mathrm{CaCO}_{3}$ itself is non-toxic, harmless and easy to use, which makes $\mathrm{CaCO}_{3}$ a great potential application for oil lubricant additives.

In this paper, the $\mathrm{CaCO}_{3}$ nanoparticles were first prepared according to literature (Chen 2010). Using tween 40 as modifier, the hydrophobic nano- $\mathrm{CaCO}_{3}$ by ultrasonic reaction were obtained. When hydrophobic nano- $\mathrm{CaCO}_{3}$ powders were as additives, the properties of vegetable oil were studied by four ball friction testing machine. The friction and wear mechanism were also discussed.

\section{Experimental}

Tween 40 and the CaCO3 (mass ratio 3\%) particles prepared by the previous methods were dissolved in anhydrous alcohol. At $75{ }^{\circ} \mathrm{C}$, the solutions were ultrasonic dispersed for $2 \mathrm{~h}$. After washing and extraction with anhydrous ethanol and deionized water, the Tween$40 \mathrm{mples}$ were centrifuged to remove impurities, and then the modified $\mathrm{CaCO}_{3}$ powders were obtained (Huang,2009).

The surface bonding structure of nanoparticles was analyzed by perkin-Elmer 400 FTIR. The contact Angle of the nano-particle was tested by the Easy drop 4014 contact Angle measurement instrument. The morphology of Tween-40mples was observed by Jeol s-4800 field emission scanning electron microscope.

The dispersion stability of lubricating oil were measured by TG16-WS centrifuge. $1 \mathrm{~g}$ additives were placed in the centrifuge tube, the solutions were centrifuged $5 \mathrm{~min}$ at 10000r/ min. The obtained precipitation is filtered,

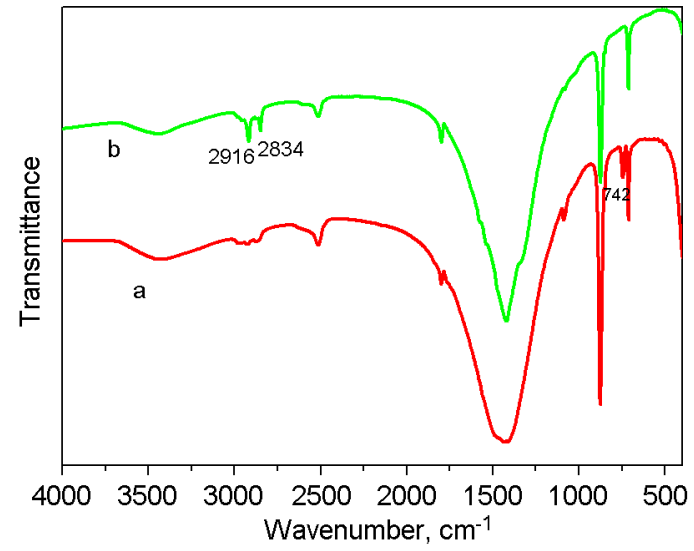

Fig. 1. FTIR spectra of $\mathrm{CaCO}_{3}$ nanoparticles(a); Tween $40-\mathrm{CaCO}_{3}(\mathrm{~b})$

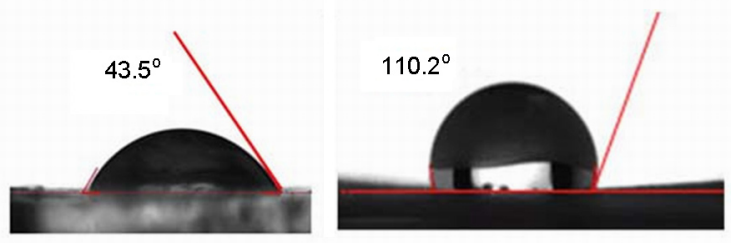

Fig. 2. Contact Angle of $\mathrm{CaCO}_{3}$ nanoparticles(a); Tween $40-\mathrm{CaCO}_{3}$ (b)

washed, dried and weighed. The higher the precipitation quality indicates that the dispersion stability is worse.

Using canola oil as base oil, the friction and wear properties of the nanoceramic powder lubricating oil were measured by a fourball friction tester. The experiment condition: steel ball is GCr15 shaped steel ball with a diameter of $12.7 \mathrm{~mm}$; the speed is of $1200 \mathrm{r} / \mathrm{min}$, the load is $392 \mathrm{~N}$, test time is $30 \mathrm{~min}$, room temperature $\left(25^{\circ} \mathrm{C}\right)$. After the test, the friction factor and the diameter of the steel ball were measured, and the steel ball was cleaned in the oil ether for 10 min to remove the oil stain on the surface of the steel ball. A metallographic microscope was used to observe the surface of the steel ball, X-ray photoelectron spectroscopy (XPS) are used to analyze the elements of the surface of the steel ball.

\section{Results and discussion}

\section{Infrared spectrum analysis}

Nano $\mathrm{CaCO}_{3}$ and Tween $40-\mathrm{CaCO}_{3}$ infrared spectra are shown in Figure 1. As can be seen from spectra of Tween 40-CaCO tion peak appeared at $2916,2854 \mathrm{~cm}^{-1}$ which are ascribed to the asymmetric and symmetric vibration of $\mathrm{CH}_{2}$. It concluded that $\mathrm{CaCO}_{3}$ were successfully modified by Tween 40 from the above results. 


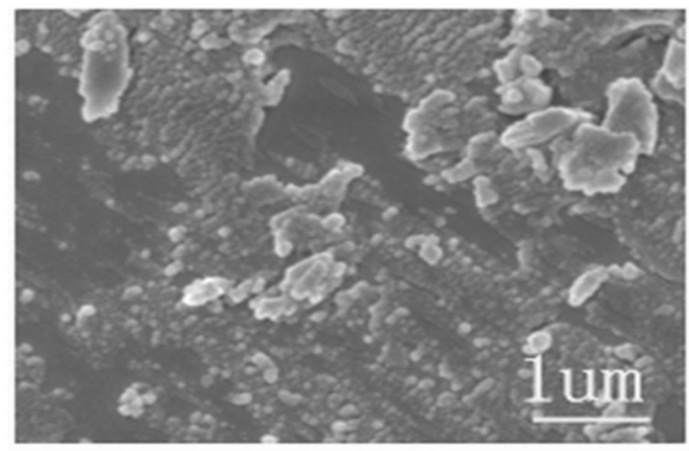

a)

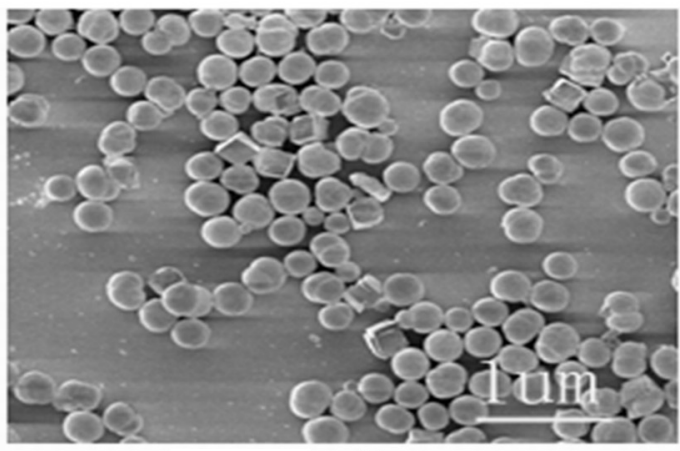

b)

Figure 3. SEM images of $\mathrm{CaCO}_{3}$ nanoparticles (a); Tween $40-\mathrm{CaCO}_{3}$ (b) Tween40 - $\mathrm{CaCO}_{3}$ dispersion stability in the rapeseed oil

\section{Contact Angle analysis}

Contact Angle of unmodified $\mathrm{CaCO}_{3}$ and Tween 40- $\mathrm{CaCO}_{3}$ are shown in Figure 2. As can be seen from the figure 2, the contact Angle of nanometer $\mathrm{CaCO}_{3}$ is $43.5^{\circ}$,indicating the surface of unmodified nano $\mathrm{CaCO}_{3}$ is hydrophilic; while the contact angle of the Tween $40-\mathrm{CaCO}_{3}$ is $110.2^{\circ}$, meaning $\mathrm{CaCO}_{3}$ surface become hydrophobicity after modified by Tween 40 .

\section{Morphology analysis}

As can be seen from Figure 3 (a), the nanoparticle $\mathrm{CaCO}_{3}$ particles are irregular particles, and there is a certain degree of reunion with the particle size of $200 \sim 400 \mathrm{~nm}$; SEM experiment displays that the Tween $40-\mathrm{CaCO}_{3}$ has amorphology of granular structure with $200 \mathrm{~nm}$ even grain size. The Tween $40-\mathrm{CaCO}_{3}$ are monodisperse nanoparticles due to the alkyl chain of Tween 40 inhibits the aggregation of $\mathrm{CaCO}_{3}$ particles.

Figure 4 shows the mass fraction of the obtained precipitation after centrifugation. As can be seen from figure 4, nanometer $\mathrm{CaCO}_{3}$ precipitates close to $100 \%$ after centrifugation, indicating the dispersion stability of unmodified nano- $\mathrm{CaCO}_{3}$ in rapeseed oil is poor. However, after centrifugation, Tween $40-\mathrm{CaCO}_{3}$, the mass fraction of the obtained precipitation is almost zero, which suggested that Tween 40 $-\mathrm{CaCO}_{3}$ in rapeseed oil and dispersing stability is good after modified by Tween-40. The differ-

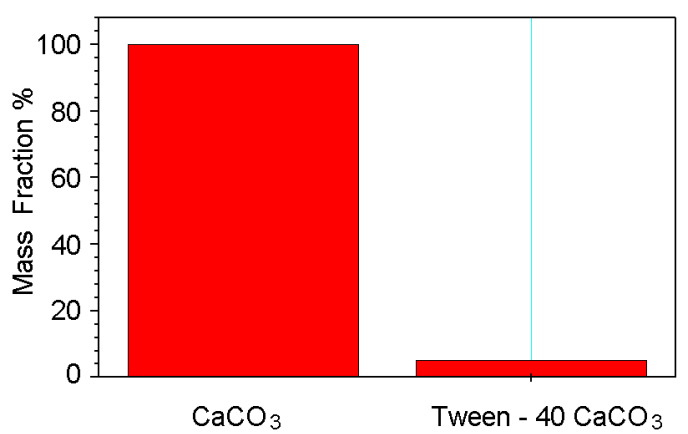

Figure 4. The mass fraction of $\mathrm{CaCO}_{3}$ nanoparticles (a); Tween $40-\mathrm{CaCO}_{3}$ (b)

ence between $\mathrm{CaCO}_{3}$ and Tween $40-\mathrm{CaCO}_{3}$ confirms the influence of the hydrophilicity on the dispersion stability.

The PPB value of rapeseed oil in this study is $667 \mathrm{~N}$, the diameter of the grinding spot is $0.54 \mathrm{~mm}$, and the friction coefficient $\mathrm{mu}$ is 0.1202 . Table 1 shows the tribological performance (Extreme pressure property(PPB), diameter of the grinding, friction coefficient) of nanometer lubricating oil change with different addition amount of $\mathrm{CaCO}_{3}$ nanoceramic powder. The tribological properties have greatly improved after adding nanocalcium carbonate to base oil. With the increasing amount of nanopowder, the extreme pressure of lubricating oil increases from $696 \mathrm{~N}$ to $755 \mathrm{~N}$ gradually, and then decrease.

Table 1 Tribological properties of Tween $40-\mathrm{CaCO}_{3}$ nanoparticles as additives in lubricating oil

\begin{tabular}{|c|c|c|c|c|c|}
\hline \multirow{2}{*}{$\begin{array}{c}\text { Tribology } \\
\text { properties }\end{array}$} & \multicolumn{5}{|c|}{$\mathrm{CaCO}_{3}$ nanoparticle additives/\% } \\
\cline { 2 - 6 } & 0.2 & 0.4 & 0.6 & 0.8 & 1.0 \\
\hline $\mathrm{PB} / \mathrm{N}$ & 696 & 726 & 755 & 726 & 696 \\
\hline $\mathrm{d} / \mathrm{mm}$ & 0.48 & 0.44 & 0.42 & 0.45 & 0.49 \\
\hline$\mu$ & 0.1005 & 0.0965 & 0.0865 & 0.0988 & 0.1132 \\
\hline
\end{tabular}




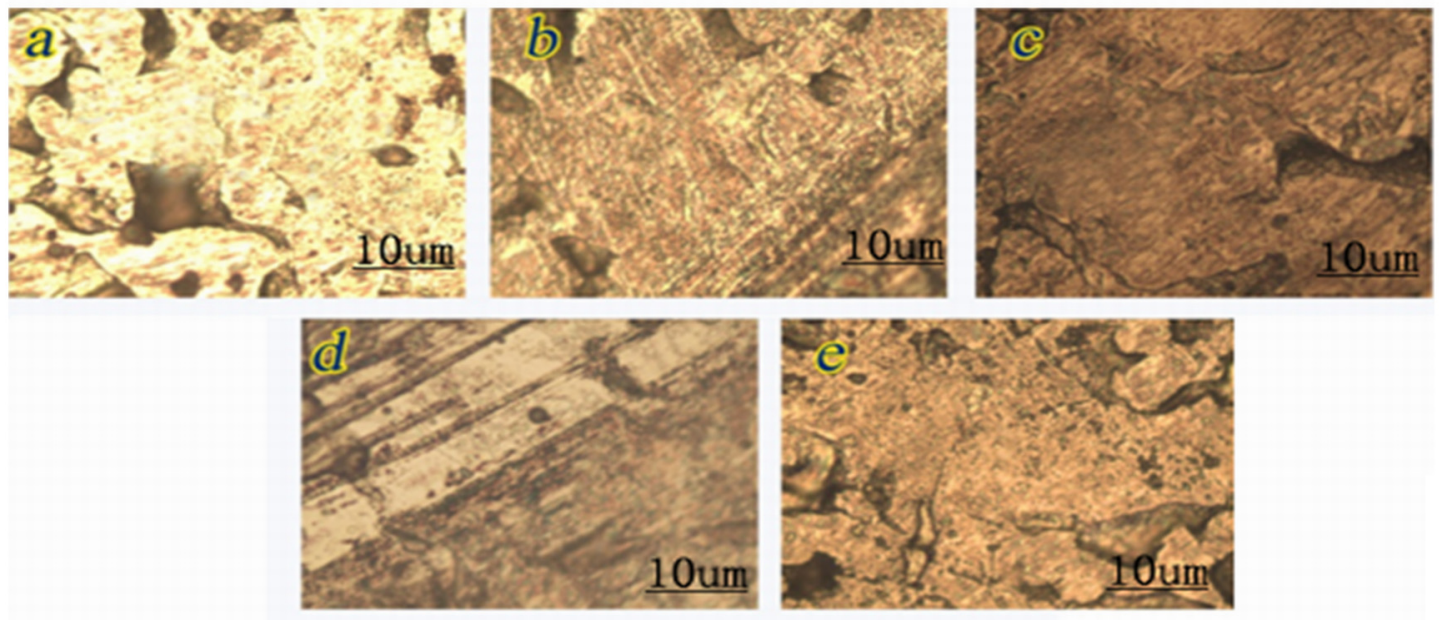

Fig. 5. Effect of different additive amounts of $\mathrm{CaCO}_{3}$ nanosized powders on morphology of friction pair surface (a) base oil; (b) Mass fraction $0.2 \%$; (c) Mass fraction0.4\%; (d) Mass fraction 0.6\% ; (e) Mass fraction $0.8 \%$; (f) Mass fraction 1\%

Table 1 also shows the average spot grinding lubricant $\mathrm{CaCO}_{3}$ ceramic powder with different mass fraction of ball diameter. Seen from the Figure, with the continuous increasing of the amount of $\mathrm{CaCO}_{3}$ ceramic powder, wear scar diameter decreases first from $0.54 \mathrm{~mm}$ to $0.42 \mathrm{~mm}$, when the concentration of nanocarbonate particles reached $0.6 \%$, the diameter of the friction increase. Compared with base oil, it can be found, the wear scar diameter of lubricating oils with $\mathrm{CaCO}_{3}$ ceramic powder additive is far less than the base oil, which shows the wear resistance of base oil has been greatly improved by the that nano $\mathrm{CaCO}_{3}$ powder.

As can be seen from Table 1 ,with the addition of nanometer calcium carbonate particles, the friction coefficient decreased from 0.1202 to 0 . 0865.The results showed that the optimum concentration of nanometer calcium carbonate was about $0.6 \%$.The above results also indicate suitable nanoparticle concentration ensure sufficient nanoparticles can be spread to form protective film on the friction surface; if adding excessive nanoparticles cannot be conducive to the lubrication performance of lubricating oil. This may be due to nanoparticles have a larger ratio surface area and surface energy, so that the excessive nanoparticles accumulate into larger particles which lead to worse tribological performance.

Fig. 5 shows the effect of the amount of farinfrared nanoceramics powder on the surface morphology of the friction pair when the magnification is 100. It can be seen from Figure $4 \mathrm{a}$, base oil lubrication of the friction surface of the largest wear surface diameter and has a more obvious furrow wear marks. From Figure 4b and Figure 4c, it can be seen that the surface of the friction pair is only slightly scratched, the surface is smooth and the diameter of the wear spot is the smallest. The results show that under the action of a small amount of nanoparticles, the new asperities and furrows generated by the friction process are quickly filled with the nanoparticles and a new lubricating film is formed, which lead to a good antifriction and antifriction effect. From Figure 4d, it can be seen that the smaller furrows appear on the surface of the friction pairs, which are more serious than those in Figure $4 \mathrm{~b}$ and 4c. Compared with the deeper furrows in the base oil, grinding performance has greatly improved. This shows that excessive nanoparticles will not continue to improve the anti-wear properties of lubricating oil, but to make it worse, which is a short time by the intervention of nanoparticles and lubricants caused by a combination of fluidity deterioration.

Fig. 6 gives XPS spectra of C, O, Fe, and $\mathrm{Ca}$ on the worn steel ball surface lubricated by containing 0.6 wt.\% modificated $\mathrm{CaCO}_{3}$ nanoparticles at $392 \mathrm{~N}$ for $30 \mathrm{~min}$. It can be seen that the peak of $\mathrm{C} 1 \mathrm{~s}$ appears at a binding energy of $284.6 \mathrm{eV}$, which is identified as $\mathrm{C}$ in air. The peak at $288.6 \mathrm{eV}$ is indicative of $\mathrm{C}$ in carboxyl group, and the carboxyl group is attributed to the Tween 40 . The weak peak at high binding energy of $290.0 \mathrm{eV}$ is associated with carbonate The O1s peak appearing at $529.6 \mathrm{eV}$ is attributed to oxygen in iron oxide and calcium oxide, while the peak at $531.8 \mathrm{eV}$ is associated with oxygen in a carboxyl group. The Fe2p peak at $710.0 \mathrm{eV}$ is attributed to the generationof iron oxide. The main Ca2p peak appearing at 347.3 $\mathrm{eV}$ is attributed to calcium in $\mathrm{CaCO}_{3}$ and the weak peak at $346.2 \mathrm{eV}$ is attributed to calcium in $\mathrm{CaO}$. From the above results. It can be concluded that the $\mathrm{CaCO}_{3}$ nanoparticles contained in the rapeseed oil are trapped inside the con- 

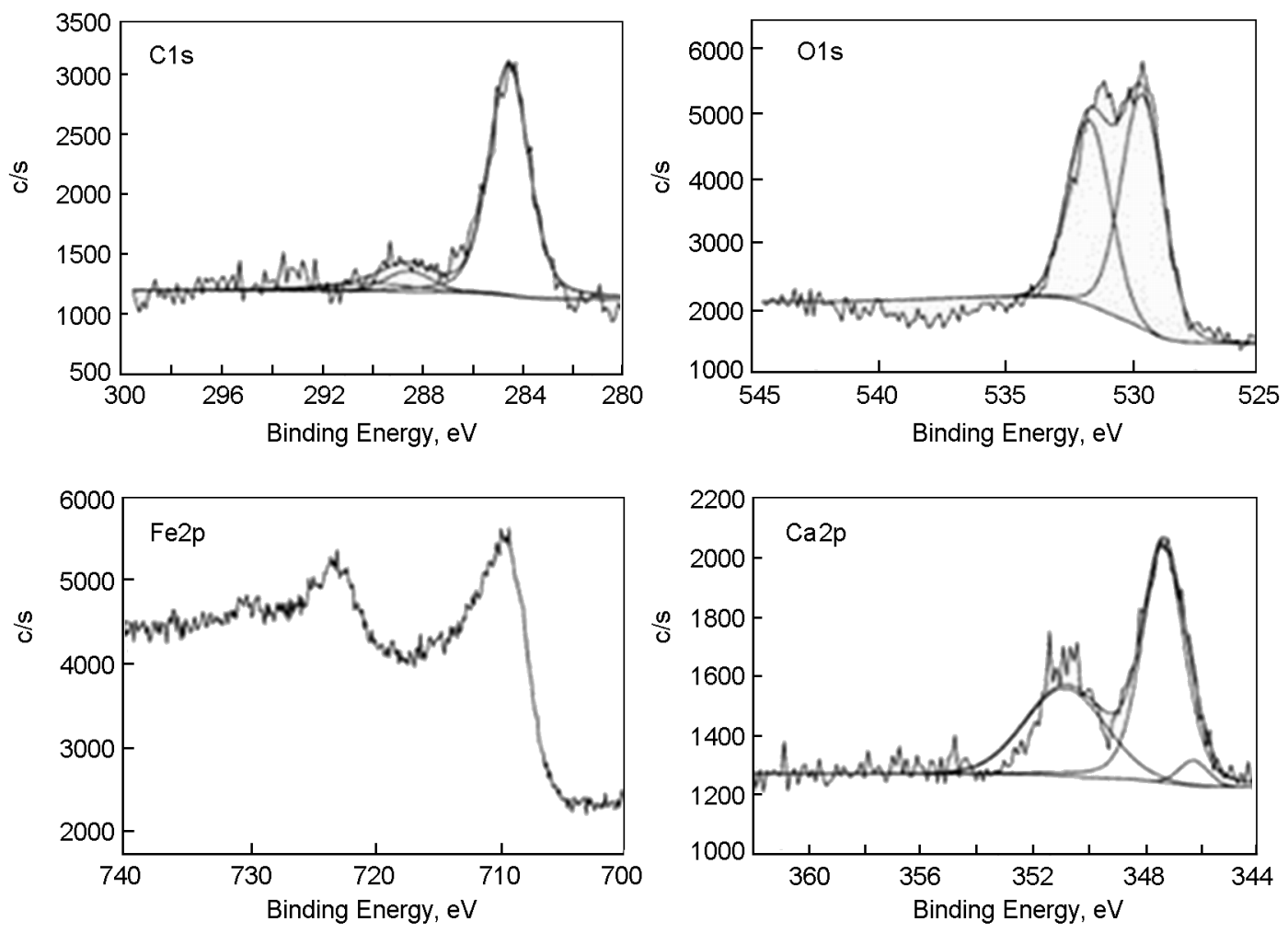

Fig. 6. XPS spectra of worn steel surface lubricated

tact and fill in the gap between the rubbing surfaces which improves the rapeseed oil antiwear and antifriction performance [5].

\section{Conclusion}

1) Using Tween-40 as the surface modifier, the Tween-40 was successfully modified on the surface of nanometer $\mathrm{CaCO}_{3}$ by ultrasonic reaction, The surface is converted from hydrophilic to hydrophobic, and the particles are not reunited with particle diameter is about 200 $\mathrm{nm}$.

2) Tween40 $-\mathrm{CaCO}_{3}$ can improve the antiwear antifriction performance of rapeseed oil,the friction factor of rapeseed oil and steel ball grinding spot diameter with Tween 40$\mathrm{CaCO}_{3}$ to decrease after the increase with the increasing of quality score; when Tween40 $\mathrm{CaCO}_{3}$ mass fraction is $0.6 \%$, canola oil antiwear and friction-reducing is best.

3) During the friction process, $\mathrm{CaCO}_{3}$ nanoparticles were deposited on the rubbing surfaces forming a boundary film. A complicated tribochemical reaction also occurred in the boundary lubrication process. From XPS analysis of the corresponding worn steel surface, it can be seen that the boundary film was composed of $\mathrm{CaCO}_{3}$ nanoparticles, $\mathrm{CaO}$, iron oxide, and other organic compounds.

\section{Acknowledgements}

The authors are grateful for the financial support provided by the Jilin Education Department Science Foundation of China (NO.2015312).

\section{References}

1. Qiao H. B., Guo Q., Mater. Mech.Eng., 29(4) , 4, 2005.

2. Huang J., Li X., Zhang Z., Adv. Tribol., 890, 2009.

3. Sun X. F., Qiao Y. L., Song W., Ma S.N., Hu C.H., Physics Proccedia, 50, 343, 2013.

4. Yang Y., Ma J., Qi X., Meng X., J. Wear, 318, 202, 2014 .

5. Chen, Y. X., Ji, X.B., Zhao, G.Q., Wang, X.B., Powder Technol., 200, 144, 2010.

6. Chen J., Tribology Letters, 38(3), 217, 2010.

7. Zhang L., Feng D., Xu B., Tribology Lett., 34 (2), 95, 2009. 